Article

AMÉRICO, G.H.P. ${ }^{*}$ AMÉRICO-PINHEIRO, J.H.P. ${ }^{1,2}$ FURLANI JR, E. ${ }^{1}$

\section{Hormesis EFFect of Dichlorophenoxy ACETIC ACID Sub-Doses and Mepiquat Chloride on CotTon Plant}

\author{
Efeito Hormese de Subdoses de Ácido Diclorofenoxiacético e Cloreto de \\ Mepiquat em Algodoeiro
}

ABSTRACT - The aim of this study was to evaluate the hormesis effect of subdoses of dichlorophenoxy acetic acid herbicide and the plant growth regulator mepiquat chloride on the vegetative and productive characteristics of two cotton cultivars (FMT 701 and Fibermax 966). The experiment was conducted from November 2013 to May 2014. The experimental design was a randomized block in a factorial scheme $6 \times 2 \times 2$, with four replications, totaling 96 installments with 24 treatments: the witness and five sub-doses of the herbicide 2,4-D: 0.68, 1.36, 2.04, 2.72 and $3.40 \mathrm{~g}$ equivalent acid (e.a) per ha, with and without application of mepiquat chloride at a dose of $200 \mathrm{~mL} \mathrm{ha}^{-1}$ in the cotton cultivars FMT 701 and Fibermax 966. The subdoses applied were 2,4-D at 45 days after the emergence of the plant (DAE), and the growth regulator was applied at $70 \mathrm{DAE}$. It was found that the use of the growth regulator (mepiquat chloride) at a dose of $200 \mathrm{~mL} \mathrm{ha}^{-1}$ was effective in controlling plant development relative to its variable height. The application of sub-doses of 2,4-D up to $1.75 \mathrm{~g}$ e.a ha-1 provides increased seed cotton productivity FMT 701 and Fibermax 966). The cultivar FMT 701 got greater plant height, stem diameter, number of reproductive branches, bolls per plant and seed cotton productivity compared to the cultivar Fibermax 966.

Keyword: Gossypium hirsutum, herbicide, growth regulator.

RESUMO - O objetivo do presente estudo foi verificar o efeito hormese de subdoses do herbicida ácido diclorofenoxiacético e do regulador de crescimento cloreto de mepiquat sobre as características vegetativas e produtivas de dois cultivares de algodoeiro (FMT 701 e Fibermax 966). O experimento foi conduzido durante $o$ periodo de novembro de 2013 a maio de 2014. O delineamento experimental foi o de blocos ao acaso, em esquema fatorial $6 \times 2 \times 2$, com quatro repetições, totalizando 96 parcelas, perfazendo 24 tratamentos: a testemunha e cinco subdoses do herbicida 2,4-D: 0,68, 1,36, 2,04, 2,72 e 3,40 g equivalente ácido (e.a.) por ha, com e sem aplicação de cloreto de mepiquat na dose de $200 \mathrm{~mL} \mathrm{ha-1}$ nos cultivares FMT 701 e Fibermax 966 de algodoeiro. Aplicou-se as subdoses de 2,4-D aos 45 dias após a emergência da planta (DAE), e do regulador de crescimento, aos 70 DAE. Constatou-se que a utilização do regulador de crescimento (cloreto de

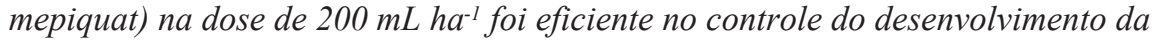
planta em relação à variável altura de planta. A aplicação de subdoses de 2,4-D

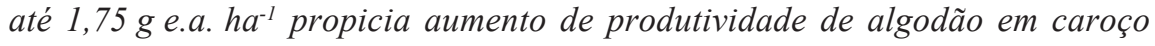
(FMT 701 e Fibermax 966). O cultivar FMT 701 obteve maior altura de planta, diametro do caule, quantidade de ramos reprodutivos, capulhos por planta e produtividade de algodão em caroço, em comparação com o cultivar Fibermax 966.

Palavra-chave: Gossypium hirsutum, herbicida, regulador de crescimento.

1 Universidade Estadual Paulista "Júlio de Mesquita Filho", Ilha Solteira-SP, Brazil; ${ }^{2}$ Fundação Educacional de Andradina, Andradina-SP, Brasil. 


\section{INTRODUCTION}

Cotton is a product of great socio-economic importance to Brazil. Besides being the most important natural source of fiber, it ensures the country is in a privileged place on the international stage as one of the five largest producers, next to China, India, the United States and Pakistan (Embrapa, 2003b).

The ninth survey of the 2015/16 crop field points to a reduction in the planted area of $1.8 \%$ in the season $2015 / 16$, reaching 958,500 hectares compared to 976,200 hectares last year. If the productivity of $3,684 \mathrm{~kg} \mathrm{ha}^{-1}$ is confirmed, the domestic production of seed cotton is expected to reach 3.531 million tons, representing a decrease of $9.7 \%$ compared to the previous harvest (Conab, 2016).

The cotton plant is a perennial plant with indeterminate growth habit, which makes the management of culture complex. The use of growth regulators is a strategy to balance the vegetative and reproductive growth of cotton, in addition to adapting the plant for mechanical harvesting and maximizing the production (Cothren and Oosterhuis, 2010). The cotton plant, when grown in natural conditions of high fertility soil or even using fertilizers, demands the use of growth regulators, as the cotton produces excessive vegetation that interferes negatively in the final production (Americo, 2015).

The use of sub-doses of substances often considered toxic to plants is an alternative for achieving productivity increase. When in small doses, these substances can stimulate plant development - a process known as "hormesis" or "hormetic effect "(Calabrese and Baldwin, 2002; Velini et al., 2008).

The responses to low doses of synthetic auxins have been analyzed by researchers for decades regarding their effect on plant growth. Studies with dichlorophenoxy acetic acid $(2,4-\mathrm{D})$ have shown "hormetic" responses in plants. Thus, the "hormetic" responses relative to some desirable characteristics of the plant could be elucidated and explored with studies on the effect on the increase in production by auxin activity (Cedergreen et al., 2007).

Therefore, the aim of this study was to evaluate the hormesis effect of sub-doses of 2,4-D herbicide and plant growth regulator mepiquat chloride in the vegetative and productive characteristics of cultivars FMT 701 and Fibermax 966 of cotton, in field conditions in lowland savannas.

\section{MATERIAL AND METHODS}

The experiment was installed in Selviria-MS, agricultural year 2013/14, with mechanized cotton planting. The corresponding geographic coordinates are: $20^{\circ} 20^{\prime} 45^{\prime \prime}$ south latitude and $51^{\circ} 24^{\prime} 11^{\prime \prime}$ west longitude, with an average altitude of $344 \mathrm{~m}$.

The climate is classified, according to Koppen (1948), as Aw, defined as tropical humid with rainy season in summer and dry in winter. It has an average annual temperature of $23.5{ }^{\circ} \mathrm{C}$, average annual rainfall of $1,370 \mathrm{~mm}$ and average relative humidity of the air $70-80 \%$ in the rainiest months (Arf et al., 2001). The soil of the experimental area was classified as Red Latosol dystrophic, according to the Brazilian soil classification (Embrapa, 2003a).

Before the experiment, a soil sampling was carried out of the experimental area for chemical characterization according to the methods of analysis described by Raij et al. (2001). In Table 1 is the result of the chemical analysis of the soil.

Based on the chemical analysis of soil, a fertilizer was used at dose of $350 \mathrm{~kg} \mathrm{ha}^{-1}$ of the NPK formulation (04-30-10) before planting the crop. The topdressing was made with $60 \mathrm{~kg} \mathrm{ha}^{-1}$ of N, divided into two applications (30 kg of $\mathrm{N}$ per application), at 30 days after emergence (DAE) and at $60 \mathrm{DAE}$, having urea as a source.

The area used for the experiment was also previously used for cotton cultivation, but in direct plantation. Therefore, the soil preparation was made by the conventional cultivation system, where plowing and harrowing were performed. After plowing, a leveling harrowing was performed and, just before the sowing, another harrowing was made, in order to eliminate weeds. 
Table 1 - Initial chemical characteristics of the soil of the experimental field at a depth of 0.0 to $0.20 \mathrm{~cm}$. Selvíria-MS, 2013

\begin{tabular}{|c|c|c|c|c|c|c|c|c|c|}
\hline \multirow{2}{*}{$\begin{array}{c}P_{\text {resina }} \\
\left(\mathrm{mg} \mathrm{dm}^{-3}\right)\end{array}$} & \multirow{2}{*}{$\begin{array}{l}\text { M.O. } \\
\left(\mathrm{g} \mathrm{dm}^{-3}\right)\end{array}$} & \multirow{2}{*}{$\begin{array}{c}\mathrm{pH} \\
\left(\mathrm{CaCl}_{2}\right)\end{array}$} & $\mathrm{K}$ & $\mathrm{Ca}$ & $\mathrm{Mg}$ & $\mathrm{H}+\mathrm{Al}$ & $\mathrm{Al}$ & CTC & \multirow{2}{*}{$\begin{array}{c}\mathrm{V} \\
(\%)\end{array}$} \\
\hline & & & \multicolumn{6}{|c|}{$\left(\mathrm{mmol}_{\mathrm{c}} \mathrm{dm}^{-3}\right)$} & \\
\hline 29 & 21 & 5.3 & 3.5 & 38 & 22 & 29 & 0 & 92.5 & 65 \\
\hline
\end{tabular}

Source: Author's elaboration.

The installation of the experiment was made on 01.12.2013, with 12 seeds per meter, with emergence of cotton plants on 12.08.2013. At $10 \mathrm{DAE}$, the thinning was made, leaving eight plants per meter in all treatments, with a population of approximately 88,900 plants per hectare. Each plot consisted of four lines of cultivation, $5 \mathrm{~m}$ long, spaced by $0.9 \mathrm{~m}$, where the usable area consists of the two main lines of the plot.

To ensure the plant emergence and establishment, irrigations were carried out by spraying with self-propelled reel winder, equipped with a sprinkler/cannon of adjustable flow.

The cultivars used have different characteristics, being cultivar FMT 701 for high sized plant and late life cycle, and cultivar Fibermax 966 for low sized and early life cycle. The products tested were the herbicide 2,4-D (CAS No. 94-75-7) in the commercial formulation DMA 806 BR, and the growth regulator mepiquat chloride (CAS No. 24307-26-4) in the commercial formulation PIX HC.

The experimental design adopted was the randomized block design (Gomes, 2000) in a 6 × 2 × 2 factorial scheme, with four replications, totaling 96 installments, with 24 treatments: the witness (without application of herbicide and plant growth regulator) and five sub-doses of the herbicide 2,4-D: 0.68, 1.36, 2.04, 2.72 and $3.40 \mathrm{~g}$ of equivalent acid (e.a) per ha ${ }^{-1}$, with and without application of mepiquat chloride at a dose of $200 \mathrm{~mL} \mathrm{ha}^{-1}$ in cotton cultivars FMT 701 and Fibermax 966.

The application of the sub-doses of the herbicide was made by foliar spraying at $45 \mathrm{DAE}$, when the plants were at growth stage $B_{4}$ (Marur and Ruano, 2001). It was used a CO2 based knapsack sprayer of constant pressure provided with XR11002 style spray tips, calibrated at 3 bar pressure and applied with spray volume of $160 \mathrm{~L} \mathrm{ha}^{-1}$.

The growth regulator (mepiquat chloride) was applied at 70 days after emergence of the cotton plant, or when the plants were in F4 stage of development, after emergence of the plants, with the dose of $50 \mathrm{~g}$ i.a. ha $^{-1}$. Sprays were made in the afternoon, with weather conditions from 22.1 to $35.1{ }^{\circ} \mathrm{C}, 55-75 \%$ relative air humidity and 0.9 to $1.3 \mathrm{~m} \mathrm{~s}^{-1}$ wind speed.

Ten plants were randomly selected in the central rows of each plot, to evaluate the following agronomic characteristics: plant height, stem diameter, number of branches and number of bolls per plant. The evaluations were performed at 45, 65, 85 and 105 DAE. Harvests were performed on two consecutive days, and the two center lines of $5 \mathrm{~m}$ long each portion were harvested.

The weeds and the pest and disease handling were conducted by spraying with products registered for cotton growing, seeking the good development of the plants so they would not interfere in the treatments under study.

The data (plant height, stem diameter, number of branches, number of bolls per plant and productivity of seed cotton) were subjected to analysis of variance by the $F$ test and the averages were compared by the Tukey test for the effect of mepiquat chloride in the cultivars. Polynomial regression was used at $5 \%$ significance level to assess the effect of doses of 2,4-D; The statistic software used was 5.1 SISVAR.

\section{RESULTS AND DISCUSSION}

The results obtained at $45 \mathrm{DAE}$ of the culture, prior to the application of doses of 2,4-D and growth regulator, were not significantly different. These results were only analyzed to verify the 
homogeneity of the plants in order to prevent them from interfering with the interpretation of results.

In the variable height of the plants, four evaluations were performed (at 45, 65, 85 and $105 \mathrm{DAE}$ ) (Table 2), where it was observed that the treatments with the application of growth regulator in the evaluations performed after 85 and $105 \mathrm{DAE}$ provided reduced growth of the cotton plant. According to Wang et al. (2014), this may be because the application of mepiquat chloride inhibit the gibberellin metabolism, which in turn inhibits the cell elongation and thus reduce the plant height, as an auxiliary hormone of auxins and cytokinins.

Regarding cultivars, there was a significant difference in all plant height assessments; the highest averages were observed in cultivar FMT 701 compared to Fibermax 966. This result was due to the agronomic characteristic size of the plant, since cultivar FMT 701 is characterized by high-growing plants, and cultivar Fibermax 966, for short plants (Bogiani and Rosolem, 2011).

The cotton plant height at 105 DAE revealed a significant interaction between the growth regulator and the sub-doses of 2,4-D (Table 2). According to the breakdown of the growth regulator in the sub-doses of 2,4-D (Table 3), it was found that the use of mepiquat chloride reduced the height of the cotton plant, regardless of the doses of 2,4-D .

The diameter of the stem of the plant (Table 4) was not affected by the application of subdoses of 2,4-D, as well as the use of growth regulator (50 g e.a. ha $\left.{ }^{-1}\right)$ noting, therefore, a stable

Table 2 - Values of $\mathrm{p}>\mathrm{F}$, polynomial regression and averages comparison test for plant height in growth regulator function (R), sub-doses of 2,4-D (D) and cotton cultivars (C) FMT 701 and Fibermax 966 . Selvíria-MS, agricultural year 2013/14

\begin{tabular}{|c|c|c|c|c|}
\hline \multirow{2}{*}{ Treatment } & \multicolumn{4}{|c|}{$p>F$} \\
\hline & $45 \mathrm{DAE}$ & $65 \mathrm{DAE}$ & $85 \mathrm{DAE}$ & $105 \mathrm{DAE}$ \\
\hline Regulator (R) & 0.76 & 0.78 & $0.00^{* *}$ & $0.00^{* *}$ \\
\hline $2,4-\mathrm{D}(\mathrm{D})$ & 0.99 & 0.99 & 0.65 & $0.02 *$ \\
\hline Cultivar (C) & $0.00^{* *}$ & $0.00 * *$ & $0.00 * *$ & $0.00^{*}$ \\
\hline $\mathrm{R}^{*} \mathrm{D}$ & 0.85 & 0.82 & 0.73 & $0.02 *$ \\
\hline $\mathrm{R}^{*} \mathrm{C}$ & 0.76 & 0.74 & 0.38 & 0.08 \\
\hline $\mathrm{D}^{*} \mathrm{C}$ & 0.96 & 0.94 & 0.24 & 0.53 \\
\hline $\mathrm{R}^{*} \mathrm{D} * \mathrm{C}$ & 0.72 & 0.73 & 0.86 & 0.13 \\
\hline VC $(\%)$ & 2.50 & 1.94 & 3.85 & 2.76 \\
\hline \multicolumn{5}{|c|}{ Tukey for the application of growth regulators (plant height, $\mathrm{cm}$ ) } \\
\hline Without application & 86.25 & 111.25 & $123.12 \mathrm{a}$ & 137.75 \\
\hline With application & 86.38 & 111.38 & $113.37 \mathrm{~b}$ & 122.45 \\
\hline LSD & 0.87 & 0.88 & 1.85 & 1.46 \\
\hline \multicolumn{5}{|c|}{ Tukey for cultivars (plant height, $\mathrm{cm}$ ) } \\
\hline FMT 701 & $88.02 \mathrm{a}$ & $119.62 \mathrm{a}$ & $123.83 \mathrm{a}$ & $145.59 \mathrm{a}$ \\
\hline Fibermax 966 & $84.62 \mathrm{~b}$ & $103.02 \mathrm{~b}$ & $112.66 \mathrm{~b}$ & $114.61 \mathrm{~b}$ \\
\hline LSD & 0.87 & 0.88 & 1.85 & 1.46 \\
\hline \multicolumn{5}{|c|}{ Regression for application of sub-doses of 2,4-D (plant height, $\mathrm{cm}$ ) } \\
\hline 0 & 86.37 & 111.37 & 118.89 & 129.90 \\
\hline 0.68 & 86.41 & 111.41 & 118.14 & 129.07 \\
\hline 1.36 & 86.21 & 111.20 & 117.18 & 128.92 \\
\hline 2.04 & 86.20 & 111.20 & 117.52 & 129.45 \\
\hline 2.72 & 86.20 & 111.20 & 119.71 & 130.67 \\
\hline 3.40 & 86.52 & 111.52 & 118.04 & 132.58 \\
\hline Linear $(p>F)$ & 0.98 & 0.98 & 0.93 & 0.01 \\
\hline Quadratic $(\mathrm{p}>\mathrm{F})$ & 0.65 & 0.65 & 0.44 & 0.02 \\
\hline
\end{tabular}

* Significant at $5 \%(\mathrm{p}<0.05)$; different letters in the column differ from each other by the Tukey test; ** significant at $1 \%$ ( $<<0.01)$; different letters in the column differ from each other by the Tukey test.

Source: Author's elaboration. 
Table 3 - Breakdown of the interaction between the sub-dose of 2,4-D and the growth regulator for plant height at 105 DAE Selvíria-MS, agricultural year 2013/2014

\begin{tabular}{|c|c|c|c|c|c|c|c|}
\hline \multirow{2}{*}{ (R) } & \multicolumn{6}{|c|}{ Sub-dose (g e.a ha -1) } & \multirow{2}{*}{ LSD } \\
\hline & 0 & 0,68 & 1,36 & 2,04 & 2,72 & 3,40 & \\
\hline With & $122.54 \mathrm{~b}$ & $123.12 \mathrm{~b}$ & $122.12 \mathrm{~b}$ & $127.12 \mathrm{~b}$ & $130.16 \mathrm{~b}$ & $131.16 \mathrm{~b}$ & \multirow{2}{*}{3.57} \\
\hline Without & $138.16 \mathrm{a}$ & $134.20 \mathrm{a}$ & $134.25 \mathrm{a}$ & $138.62 \mathrm{a}$ & $140.27 \mathrm{a}$ & $140.54 \mathrm{a}$ & \\
\hline
\end{tabular}

Averages followed by the same letter in the columns do not statistically differ from each other by the Tukey test at $5 \%$ probability. Source: Author's elaboration.

Table 4 - Values of $\mathrm{p}>\mathrm{F}$, polynomial regression and averages comparison test for plant stem diameter in growth regulator function (R), sub-doses of 2,4-D (D) and cotton cultivars (C) FMT 701 and Fibermax 966. Selvíria-MS, agricultural year 2013/14

\begin{tabular}{|c|c|c|c|c|}
\hline \multirow{2}{*}{ Treatment } & \multicolumn{4}{|c|}{$p>F$} \\
\hline & $45 \mathrm{DAE}$ & $65 \mathrm{DAE}$ & $85 \mathrm{DAE}$ & $105 \mathrm{DAE}$ \\
\hline Regulator (R) & 0.88 & 0.25 & 0.57 & 0.61 \\
\hline $2,4-\mathrm{D}(\mathrm{D})$ & 0.99 & 0.97 & 0.52 & 0.78 \\
\hline Cultivar (C) & $0.01 * *$ & $0.00 * *$ & $0.00 * *$ & $0.00 * *$ \\
\hline $\mathrm{R} * \mathrm{D}$ & 0.99 & 0.92 & 0.86 & 0.54 \\
\hline $\mathrm{R} * \mathrm{C}$ & 0.78 & 0.74 & 0.49 & 0.90 \\
\hline $\mathrm{D} * \mathrm{C}$ & 0.99 & 0.82 & 0.80 & 0.96 \\
\hline $\mathrm{R} * \mathrm{D} * \mathrm{C}$ & 0.99 & 0.86 & 0.67 & 0.93 \\
\hline $\mathrm{VC}(\%)$ & 7.20 & 3.19 & 2.51 & 2.60 \\
\hline \multicolumn{5}{|c|}{ Tukey for the application of growth regulator (stem diameter, $\mathrm{cm}$ ) } \\
\hline Without application & 0.67 & 0.99 & 1.23 & 1.25 \\
\hline With application & 0.67 & 0.99 & 1.23 & 1.25 \\
\hline LSD & 0.01 & 0.05 & 0.01 & 0.01 \\
\hline \multicolumn{5}{|c|}{ Tukey for cultivars (stem diameter, $\mathrm{cm}$ ) } \\
\hline FMT 701 & 0.67 & 0.99 & 1.23 & 1.25 \\
\hline Fibermax 966 & 0.67 & 0.99 & 1.23 & 1.25 \\
\hline LSD & 0.01 & 0.05 & 0.01 & 0.01 \\
\hline \multicolumn{5}{|c|}{ Regression for application of sub-doses of 2,4-D (stem diameter, $\mathrm{cm}$ ) } \\
\hline 0 & 0.67 & 0.99 & 1.23 & 1.26 \\
\hline 0.68 & 0.68 & 0.99 & 1.22 & 1.25 \\
\hline 1.36 & 0.67 & 0.98 & 1.22 & 1.25 \\
\hline 2.04 & 0.67 & 0.99 & 1.22 & 1.24 \\
\hline 2.72 & 0.67 & 0.98 & 1.23 & 1.25 \\
\hline 3.40 & 0.68 & 0.99 & 1.24 & 1.25 \\
\hline Linear $(p>F)$ & 0.71 & 0.75 & 0.21 & 0.74 \\
\hline Quadratic $(\mathrm{p}>\mathrm{F})$ & 0.96 & 0.81 & 0.13 & 0.45 \\
\hline
\end{tabular}

* Significant at $5 \%(\mathrm{p}<0.05)$; different letters in the column differ from each other by the Tukey test; ** significant at $1 \%(\mathrm{p}<0.01)$; different letters in the column differ from each other by the Tukey test.

Source: Author's elaboration.

characteristic in relation to the handling use of these products. The same results were observed by Azevedo et al. (2004) on cotton after a single application of $50 \mathrm{~g} \mathrm{ha}^{-1}$ of mepiquat chloride, but these authors found that from two split applications of $50 \mathrm{~g} \mathrm{ha}^{-1}$, the growth regulator reduces the diameter of the stem of the plant.

For both cultivars evaluated, a significant difference in diameter of the stem of the plant occured in all evaluations. The biggest averages of stem diameter were recorded in the cultivar FMT 701 in all evaluation periods. This result was expected because the cultivar FMT 701 
shows genotypic characteristics that favor a better development of stem diameter, compared to Fibermax 966.

Regarding the number of reproductive branches of the plant (Table 5), there was no significant difference to sub-doses of herbicide and growth regulator. These results are similar to those obtained by Bogiani and Rosolem (2009), who found no effect of growth regulator application (mepiquat chloride) in the number of reproductive branches. For Souza (2007), the number of reproductive branches was significantly influenced by the growth regulator doses (15 and $\left.30 \mathrm{~g} \mathrm{ha}^{-1}\right)$. The application ofmepiquat chloride resulted in plants with reduced number of reproductive branches when compared to treatment without the regulator application.

For the cultivars, it was found a difference in the number of reproductive branches, both in the initial assessment (45 and $65 \mathrm{DAE}$ ) and the final (85 and $105 \mathrm{DAE}$ ). The cultivar FMT 701 presented higher number of reproductive branches in the plant than the cultivar Fibermax 966, and this characteristic is related to the cultivar.

In the amount of reproductive structures and productivity of the seed cotton (Table 6), it was found that the sub-doses of 2,4-D significantly influence the number of reproductive structures in assessments performed at 65, 85 and $105 \mathrm{DAE}$ and in the productivity of the seed cotton.

It was observed that in the assessment performed at $65 \mathrm{DAE}$, there was a linear increase to the amount of reproductive structures with the application of 2,4-D, i.e., the increase in the number of reproductive structures was provided by increasing the sub-doses of 2,4-D.

Table 5 - Values of $\mathrm{p}>\mathrm{F}$, polynomial regression and averages comparison test for number of branches in growth regulator function (R), sub-doses of 2,4-D (D) and cotton cultivars (C) FMT 701 and Fibermax 966. Selvíria-MS, agricultural year 2013/14

\begin{tabular}{|c|c|c|c|c|}
\hline \multirow{2}{*}{ Treatment } & \multicolumn{4}{|c|}{$p>F$} \\
\hline & $45 \mathrm{DAE}$ & $65 \mathrm{DAE}$ & $85 \mathrm{DAE}$ & $105 \mathrm{DAE}$ \\
\hline Regulator (R) & 0.88 & 0.37 & 0.45 & 0.40 \\
\hline 2,4-D (D) & 0.46 & 0.88 & 0.09 & 0.91 \\
\hline Cultivar (C) & $0.00 * *$ & $0.00^{* *}$ & $0.00 * *$ & $0.00^{* *}$ \\
\hline $\mathrm{R} * \mathrm{D}$ & 0.98 & 0.36 & 0.55 & 0.37 \\
\hline $\mathrm{R}^{* \mathrm{C}}$ & 0.49 & 0.97 & 0.68 & 0.99 \\
\hline $\mathrm{D} * \mathrm{C}$ & 0.91 & 0.11 & 0.29 & 0.13 \\
\hline $\mathrm{R} * \mathrm{D} * \mathrm{C}$ & 0.68 & 0.25 & 0.23 & 0.27 \\
\hline $\mathrm{VC}(\%)$ & 8.48 & 9.27 & 10.26 & 8.35 \\
\hline \multicolumn{5}{|c|}{ Tukey for the application of growth regulator (reproductive branches) } \\
\hline Without application & 8.66 & 15.10 & 16.26 & 16.75 \\
\hline With application & 8.64 & 14.86 & 16.44 & 16.49 \\
\hline LSD & 0.10 & 0.56 & 0.47 & 0.56 \\
\hline \multicolumn{5}{|c|}{ Tukey for cultivars (reproductive branches) } \\
\hline FMT 701 & $9.01 \mathrm{a}$ & $15.93 \mathrm{a}$ & $11.97 \mathrm{a}$ & $17.63 \mathrm{a}$ \\
\hline Fibermax 966 & $8.29 b$ & $14.24 \mathrm{~b}$ & $10.73 \mathrm{~b}$ & $15.52 \mathrm{~b}$ \\
\hline LSD & 0.29 & 0.55 & 0.47 & 0.55 \\
\hline \multicolumn{5}{|c|}{ Regression for application of sub-doses of 2,4-D (reproductive branches) } \\
\hline 0 & 8.56 & 14.69 & 15.06 & 16.51 \\
\hline 0.68 & 8.58 & 15.11 & 15.01 & 16.38 \\
\hline 1.36 & 8.41 & 15.00 & 14.80 & 16.86 \\
\hline 2.04 & 8.64 & 14.89 & 15.67 & 16.55 \\
\hline 2.72 & 8.87 & 14.73 & 14.79 & 16.51 \\
\hline 3.40 & 8.84 & 15.12 & 14.57 & 16.40 \\
\hline Linear $(\mathrm{p}>\mathrm{F})$ & 0.10 & 0.66 & 0.12 & 0.67 \\
\hline Quadratic $(\mathrm{p}>\mathrm{F})$ & 0.41 & 0.80 & 0.09 & 0.81 \\
\hline
\end{tabular}

* Significant at $5 \%(\mathrm{p}<0.05)$; different letters in the column differ from each other by the Tukey test; ** significant at $1 \%(\mathrm{p}<0.01)$; different letters in the column differ from each other by the Tukey test.

Source: Author's elaboration. 
AMÉRICO, G.H.P., AMÉRICO-PINHEIRO, J.H.P. and FURLANI JR, E. Hormesis effect of dichlorophenoxy acetic acid sub-doses ...

Table 6 - Values of $\mathrm{p}>\mathrm{F}$, polynomial regression and averages comparison test for reproductive structures and seed productivity in growth regulator function (R), doses of 2,4-D (D) and cotton cultivars (C) FMT 701 and Fibermax 966. Selvíria-MS, agricultural year 2013/14

\begin{tabular}{|c|c|c|c|c|c|}
\hline \multirow{2}{*}{ Treatment } & \multicolumn{4}{|c|}{$\mathrm{p}>\mathrm{F}$} & \multirow{2}{*}{$\begin{array}{l}\text { Productivity } \\
\left(\mathrm{kg} \mathrm{ha}^{-1}\right)^{(4)}\end{array}$} \\
\hline & $45 \mathrm{DAE}$ & $65 \mathrm{DAE}^{(1)}$ & $85 \mathrm{DAE}^{(2)}$ & $105 \mathrm{DAE}^{(3)}$ & \\
\hline \multicolumn{6}{|c|}{ Reproductive structure } \\
\hline Regulator $(\mathrm{R})$ & 0.08 & 0.24 & 0.39 & 0.40 & 0.98 \\
\hline 2,4-D (D) & 0.33 & $0.01 * *$ & $0.00 * *$ & $0.00 * *$ & $0.01 * *$ \\
\hline Cultivar (C) & $0.00 * *$ & $0.00 * *$ & $0.05^{*}$ & $0.00 * *$ & $0.00 * *$ \\
\hline $\mathrm{R} * \mathrm{D}$ & 0.99 & 0.66 & 0.10 & 0.47 & 0.92 \\
\hline $\mathrm{R} * \mathrm{C}$ & 0.97 & 0.76 & 0.46 & 0.23 & 0.55 \\
\hline $\mathrm{D}^{*} \mathrm{C}$ & 0.14 & 0.95 & 0.28 & 0.72 & 0.60 \\
\hline $\mathrm{R} * \mathrm{D} * \mathrm{C}$ & 0.76 & 0.99 & 0.52 & 0.61 & 0.90 \\
\hline $\mathrm{VC}(\%)$ & 10.99 & 14.04 & 13.44 & 7.36 & 13.85 \\
\hline \multicolumn{6}{|c|}{ Tukey for the application of growth regulator } \\
\hline Without application & 9.74 & 9.37 & 12.56 & 17.72 & 1889.30 \\
\hline With application & 10.15 & 9.69 & 12.27 & 17.50 & 1890.23 \\
\hline LSD & 0.44 & 0.54 & 0.67 & 0.52 & 106.54 \\
\hline \multicolumn{6}{|c|}{ Tukey for cultivars } \\
\hline FMT 701 & $12.68 \mathrm{a}$ & $10.85 \mathrm{a}$ & 12.17 & $18.17 \mathrm{a}$ & $2100.83 \mathrm{a}$ \\
\hline Fibermax 966 & $7.21 \mathrm{~b}$ & $8.21 \mathrm{~b}$ & 12.65 & $17.06 \mathrm{~b}$ & $1678.70 \mathrm{~b}$ \\
\hline LSD & 0.44 & 0.54 & 0.67 & 0.52 & 106.54 \\
\hline \multicolumn{6}{|c|}{ Regression for the application of sub-doses of 2,4-D } \\
\hline 0 & 9.54 & 9.68 & 10.43 & 15.97 & 1689.58 \\
\hline 0.68 & 9.62 & 10.14 & 12.12 & 16.73 & 1987.91 \\
\hline 1.36 & 10.86 & 10.21 & 12.04 & 17.43 & 1966.38 \\
\hline 2.04 & 10.19 & 10.08 & 13.12 & 18.62 & 1972.50 \\
\hline 2.72 & 10.23 & 8.54 & 14.57 & 19.35 & 1972.08 \\
\hline 3.40 & 10.01 & 9.95 & 12.19 & 17.58 & 1750.14 \\
\hline Linear $(p>F)$ & 0.07 & $0.01 *$ & $0.00 * *$ & $0.00 *$ & 0.63 \\
\hline Quadratic $(\mathrm{p}>\mathrm{F})$ & 0.99 & 0.52 & $0.00 *$ & $0.00^{*}$ & $0.01 *$ \\
\hline
\end{tabular}

(1) Linear equation: $\mathrm{Y}=-0.39 \mathrm{x}+10.21\left(\mathrm{R}^{2}=60.13 \%\right)$; ${ }^{(2)}$ Quadratic equation: $\mathrm{Y}=-0.55 \mathrm{x}^{2}+2.59 \mathrm{x}+10.33\left(\mathrm{R}^{2}=70.80 \%\right)$; ${ }^{(3)} \mathrm{Quadratic}$ equation: $\mathrm{Y}=-0.48 \mathrm{x}^{2}+2.36 \mathrm{x}+15.65\left(\mathrm{R}^{2}=65.10 \%\right)$; ${ }^{(4)}$ Quadratic equation: $\mathrm{Y}=-97.20 \mathrm{x}^{2}+341.46 \mathrm{x}+1721.27\left(\mathrm{R}^{2}=66.13\right)$. * Significant at $5 \%(\mathrm{p}<0.05)$; different letters in the column differ from each other by the Tukey test; ${ }^{*}$ significant at $1 \%(\mathrm{p}<0.01)$; different letters in the column differ from each other by the Tukey test.

Source: Author's elaboration.

Therefore, the application of sub-doses of synthetic auxin, like 2,4-D, caused changes in the reproductive growth in cotton, providing greater amount of reproductive structures. This shows that the 2,4-D herbicide in low concentrations stimulates the synthesis of RNA, DNA and proteins, which in turn influences the development of flower buds (Taiz and Zaiger, 2004).

In the assessment performed at $85 \mathrm{DAE}$, it was found that the number of reproductive structures had quadratic fit for the sub-doses of 2,4-D with maximum herbicide efficiency obtained in sub-dose of $2.35 \mathrm{~g}$ e.a ha ${ }^{-1}$, which is equivalent to approximately 14 reproductive structures per plant. In the assessment performed at $105 \mathrm{DAE}$, the number of reproductive structures was adjusted to a quadratic equation to increasing sub-doses of 2,4-D, reaching a maximum point of sub-dose of the product with $2.45 \mathrm{~g}$ e.a. ha $^{-1}$, which corresponds to approximately 19 reproductive structures. In these two assessments, it is possible to infer the likely occurrence of the Hormesis effect, i.e., when the herbicide used in sub-doses stimulates the plant growth (Smith et al., 2012).

The seed cotton productivity showed differences, setting a quadratic equation to increasing

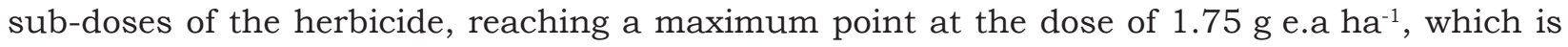
equivalent to a seed cotton productivity of $2,021.15 \mathrm{~kg} \mathrm{ha}^{-1}$. These results are in agreement with 
those of Furlani Junior et al. (2011) which found an increase in the number of reproductive structures in cultivar FMT 701 with the increase of 2,4-D sub-doses, observing a difference of about $21 \%$ when compared to the sub-dose of 2.72 g e.a. $\mathrm{h}^{-1}$, relative to the control.

For the cultivars, a significant difference in all evaluations of the number of reproductive structures and seed cotton productivity were observed. The cultivar FMT 701, compared with the Fibermax 966 had more reproductive structures and higher productivity in seed cotton at low altitude savannah conditions.

\section{ACKNOWLEDGMENT}

To the Coordenação de Aperfeiçoamento de Pessoal de Nivel Superior (CAPES) for the postgraduation scholarships granted for both authors.

\section{REFERENCES}

Américo G.H.P. Crescimento e produtividade do algodoeiro em função da aplicação de subdoses de 2,4-D e cloreto de mepiquat. [Dissertação]. Ilha Solteira: Faculdade de Engenharia de Ilha Solteira, Universidade Estadual Paulista, 2015.

Arf O. et al. Resposta de cultivares de arroz de sequeiro ao preparo do solo e à irrigação por aspersão. Pesq Agropec Bras. 2001;36:871-9.

Azevedo D.M.P. et al. Efeito do parcelamento do cloreto de mepiquat em algodoeiro irrigado no nordeste brasileiro. Rev Bras Oleag Fibr. 2004;8:823-30.

Bogiani J.C., Rosolem C.A. Sensibilidade de cultivares de algodoeiro ao cloreto de mepiquat. Pesq Agropec Bras. 2009;44:1246-53.

Bogiani J.C., Rosolem C.A. Resposta de crescimento, matéria seca e fotossíntese do algodoeiro pelo uso de cloreto de mepiquat. Rev Bras Oleag Fibr. 2011;15:9-16.

Calabrese E.J., Baldwin L.A. Defining hormesis. Human Exper Toxicol. 2002;21:91-7.

Cedergreen N. et al. The occurrence of hormesis in plants and algae. Dose-Response. 2007;5:150-62.

Empresa Brasileira de Pesquisa Agropecuária - Embrapa. Algodão tolerante à seca. Brasília: 2003a. [acessado em: jan. de 2016] Disponível em: https://www.embrapa.br/busca-de-noticias/-/noticia/8535147/algodao-tolerante-a-seca.

Empresa Brasileira de Pesquisa Agropecuária - Embrapa. Cultura do algodoeiro no cerrado. Campina Grande: 2003b. [acessado em: jan. de 2015] Disponível em: http://sistemasdeproducao.cnptia.embrapa.br/FontesHTML/Algodao/AlgodaoCerrado/index.htm.

Companhia Nacional de Abastecimento - Conab. Acompanhamento de safra brasileira: grãos, nono levantamento. 2016. [acessado em mar. de 2016] Disponível em: http://www.conab.gov.br.

Cothren J.T., Oosterhuis D.M. Use of growth regulators in cotton production. In: Stewart J.McD. et al., editores. Physiology of cotton. Dordrecht: Springer, 2010. p.289-303.

Furlani Junior E. et al. Efeito de subdoses de 2,4-D sobre componestes da produção do algodoeiro. In: Anais do $8^{\mathrm{a}}$ Congresso Brasileiro de Algodão. Campina Grande: Embrapa Algodão, 2011. p.599-604.

Gomes P.F. Curso de estatística experimental. 14ª .ed. Piracicaba: Nobel, 2000. 460p.

Marur C.A., Ruano O.A. A reference system for determination of developmental stages of upland cotton. Rev Oleag Fibr. 2001;5:313-7.

Raij B van. et al. Análise química para avaliação da fertilidade de solos tropicais. Campinas: Instituto Agronômico, 2001. 284 p.

Silva R.A. et al. Aplicação de subsodes de glyphosate na fase de estabelecimento da cultura da soja e do milho. Enciclopédia Biosfera. 2012;8:140-9. 
Souza F.S. Ação de reguladores de crescimento no algodoeiro em função da ocorrência de chuvas, temperatura e adjuvante. [Tese]. Botucatu: Faculdade de Ciências Agronômicas, Universidade Estadual Paulista, 2007.

Taiz L., Zeiger E. Fisiologia vegetal. $3^{\mathrm{a}}$ ed. Porto Alegre: Artmed, 2004. 719p.

Velini E.D. et al. Glyphosate applied at low doses can stimulate plant growth. Pestic Manage Sci. 2008;64:489-9.

Wang L. et al. The effect of mepiquat chloride on elongation of cotton (Gossypium hirsutum L.) internode is associated with low concentration of gibberellic acid. Plant Sci. 2014;225:15-23. 